\title{
Empirical Study on China's position in the global value chain of Electronic Information Manufacturing Industry
}

\author{
Chen $\mathrm{Yu}^{1}$,Mao Chengcheng ${ }^{1,}{ }^{*}$ and Huang jinglei ${ }^{1}$ \\ ${ }^{1}$ School of Economics and Commerce of South China University of Technology, \\ Guangzhou 510006, China \\ *email:ccfy468@126.com
}

\begin{abstract}
High-tech industry involves many production links. Trade volume includes foreign valueadded, which cannot truly reflect the status of this manufacturing industry in the international division of labor. In order to restore the real profitability of each economy, this paper measures the export value of the electronic information manufacturing industry from 2000 to 2011 based on KPWW method and decomposes country's exports into five components. The empirical results show that the export volume of electronic information manufacturing industry in our country seems to be huge for a long time, but it contains a large amount of foreign value-added, and the double counted ratio was as high as $31.39 \%$ in 2011. The gap of the GVC position index of electronic information manufacturing industry between China and other countries is very evident, and China lies downstream in Global Value Chain. At the same time, the trend that its exports are consumed directly as final goods abroad is weakening. The domestic value-added embodied in intermediate exports used by the direct importer to produce goods shipped back to in China has risen gradually. The pace of overseas production of electronic information manufacturing industry is accelerating.
\end{abstract}

Key words: KPWW method, Global Value Chain, Double counted, GVC position index

\section{Introduction}

At present, China is the biggest consumer of consumer electronics in the world and also is the largest manufacturing base of consumer electronics in the world. "Made in China" brand also has a good performance in the international market. Electronic information manufacturing industry is a technology-intensive industry, representing the new direction of economic development. In 2015, China's exports of electronic information products amounted to 781.1 billion US dollars, down by $1.1 \%$, accounting for $34.3 \%$ of the country's exports. The trade surplus of such products was 253.4 billion US dollars, accounting for $42.7 \%$ of the country's trade surplus. As the same time, with the rate of trade in intermediate products surpassing the final product, it is also clear that the drawbacks of traditional statistics on trade values are becoming more pronounced. Traditional statistics assumes that the value of an exported product is simply created by a country or region in which a country's exports are equal to the total value created by the country. When the production of export products need to import a large number of intermediate products, this statistical method will overestimate the real value creation ability of this country and thus it can easily lead to trade disputes and other issues.

The electronic and optical equipment industry ${ }^{2}$ is one of the industries with the largest number of processes segmented in the Global Value Chain (GVC)(Wang, 2014), so the goss exports contain more foreign value-added and cannot truly reflect the status of international division of labor of the manufacturing sector. In order to restore the real ability of the profits creation of the various economies, the question of "who creates the value" has aroused the interest of domestic and foreign scholars. The value-added measurement method has become an important breakthrough. Based on KPWW method, this paper measures the export value of the electronics information manufacturing industry from 2000 to

\footnotetext{
${ }^{1}$ Source: Ministry of Industry and Information Technology of the People's Republic of China.

${ }^{2}$ Electronic information manufacturing industry mainly includes computer, communication equipment, digital audio-visual, integrated circuit, electronic components, electronic materials, new display devices, electronic special equipment and instruments, light-emitting diodes and solar photovoltaic. The World Input-Output Tables(WIOTs) is classified according to ISIC Rev. 3, among which Electrical and Optical Equipment (c14) includes office, accounting and computing facilities and other Electrical and appliance production, broadcasting and television and communications equipment and instruments and medical, precision and optical instruments and watches, and other production. In this paper, "c14" in the WIOTs is chosen to represent the electronic information manufacturing industry.
} 
2011 and decomposes domestic value added .Then this paper calculates the proportion of domestic value added in gross export and analyzes the distribution pattern of trade benefits among many countries. Finally, this paper also depicts the position of China's electronic information manufacturing industry in GVC.

\section{Literature Review}

Within the global production networks, value arises from multiple stakeholders. Tracing their value added sources and measuring their contribution to exports have far-reaching implications for academic research and policy-making. In this regard, Hummels et al. (2001) proposed Vertical Specialization measurement method and had been widely used, referred to HIY method. The disadvantage of HIY is that it does not take into account the indirect value-added through exports of third countries when measuring the share of foreign value-added(VS) in exports, nor does it fully analyze the root causes of the value added in gross exports. In addition, Daudin et al.(2011) proposed VS1*, which focused on calculating domestic value added that returned home in imports, solving the shortcomings of the calculation method of the domestic value (VS1) of foreign imports was not proposed by HIY. Johnson (2012) loosened HIY's hypothesis that the value of exports completely remained abroad, presented the ratio of value added exports to gross exports (VAX), and reduced the size of Sino-US trade imbalances by $30 \%$ to $40 \%$ in 2004 by using the new methodology, which reflected that the traditional statistical methods exaggerated the Sino-US trade balance.

Koopman's method, decomposing gross export value, integrates and generalizes the many attempts in the literature at tracing value added by country in international trade. The method, which to be called KPWW method, proposes a conceptual framework for analyzing countries production chain participation and value added in international trade process. Koopman(2010) drawn on the essence of previous studies to decompose the value-added approach and divide the gross exports into five parts. At the same time, Koopman also proposed a specific indicator of the international division of labor status of a country, namely "GVC_Position", he believed that if the country-sector lies upstream in a supply chain, they are more inclined to participate in the international division of labor by providing intermediates, then the higher the value of the indicator, and vice versa. Zhou Shengqi et al.(2014)based on OECD \& WTO joint database on Trade in Value Added (TiVA), found that the division status of China's manufacturing industry and its sectors in GVC from 1995 to 2009 took on an L-shaped evolution. The main causes for this characteristic are attributable to China's factor endowment, industrialization and change of economic development strategies.

Koopman (2010) did not provide the idea of GVC upgrade, but the accounting method based on input-output table could accurately trace the origin, flow and destination of value added. Masaaki et al. (2014) studied traditional trade balance and value added trade balance, and found that the value added trade balance calculated by Koopman's method was not equal to the trade balance value of customs statistics, and the method proposed by Johnson was equal. On the empirical side, Masaaki used the World Input-Output Table (WIOT) to measure the trade relationship between China and the United States, and found that based on value-added accounting, China's trade surplus with the US declined by $23.5 \%$ compared with the traditional customs statistics. Li Jinchang and Xiang Ying (2014) analyzed on the value-added share of China's manufacturing sector as a whole and 14 sub-sectors and its country(region) source from 1995 to 2009.In summary, the KPWW method is a breakthrough of the research methods of trade in value-added. Domestic and foreign scholars have begun to use different value-added methods to measure the trade value, but very few study splits trade value and traces value-added in gross exports for the specific industry.

\section{Value Chain Calculation of Electronic Information Manufacturing Industry}

This paper uses KPWW research method that Koopman et al. (2010) proposed on the basis of production principle of non-competitive input-output tables, to decompose the value of different sources in exports of electronic information manufacturing industry and calculate its position in the GVC.

\subsection{Decomposing Gross Trade into Value Added Components}


Assuming there are $\mathrm{n}$ countries and each country has $\mathrm{m}$ sectors. All gross output produced by country $\mathrm{c}$ must be used as either an intermediate good or a final good, either at home or abroad. $x_{c}$ has to satisfy the following accounting relationship:

$$
x_{c}=a_{c c} x_{c}+\sum_{r \neq c}^{n} a_{c r} x_{r}+f_{c c}+\sum_{r \neq c}^{n} f_{c r}, c=1,2, . ., n
$$

On the right-hand side of equation (1), the first two terms represent that gross output are used as an intermediate goods at home or abroad, the latter two terms are used as a final good in domestic and foreign countries. Where $x_{c}$ and $x_{r}$ respectively denote domestic and foreign country s' gross output, and $a_{c r}$ is the input-output coefficient, $f_{c r}$ is the final demand in country $\mathrm{r}$ for the final good produced in $\mathrm{c}$. $a_{c c} x_{c}$ and $f_{c c}$ are respectively that a country uses intermediates and final goods produced by its own production. The global input-output system is given succinctly by block matrix notations:

$$
\begin{gathered}
{\left[\begin{array}{l}
X_{1} \\
X_{2} \\
\ldots \\
X_{n}
\end{array}\right]=\left(\begin{array}{ccc}
A_{11} & \ldots & A_{1 n} \\
\vdots & \ddots & \vdots \\
A_{n 1} & \cdots & A_{n n}
\end{array}\right)\left[\begin{array}{l}
X_{1} \\
X_{2} \\
\ldots \\
X_{n}
\end{array}\right]+\left(\begin{array}{c}
F_{11}+F_{12}+\ldots+F_{1 n} \\
\ldots \\
F_{n 1}+F_{n 2}+\ldots+F_{n n}
\end{array}\right)} \\
{\left[\begin{array}{l}
X_{1} \\
X_{2} \\
\ldots \\
X_{n}
\end{array}\right]=\left(\begin{array}{ccc}
I-\mathrm{A}_{11} & \ldots & -\mathrm{A}_{n 1} \\
\vdots & \ddots & \vdots \\
-\mathrm{A}_{n 1} & \cdots & \mathrm{I}^{-\mathrm{A}_{n n}}
\end{array}\right)^{-1}\left(\begin{array}{c}
F_{11}+F_{12}+\ldots+F_{1 n} \\
\ldots \\
F_{n 1}+F_{n 2}+\ldots+F_{n n}
\end{array}\right)=\left(\begin{array}{ccc}
B_{11} & \ldots & B_{1 n} \\
\vdots & \ddots & \vdots \\
B_{n 1} & \cdots & B_{n n}
\end{array}\right)\left(\begin{array}{c}
F_{11}+F_{12}+\ldots+F_{1 n} \\
\ldots \\
F_{n 1}+F_{n 2}+\ldots+F_{n n}
\end{array}\right)} \\
\left(\begin{array}{ccc}
X_{11} & \ldots & X_{1 \mathrm{n}} \\
\vdots & \ddots & \vdots \\
X_{n 1} & \cdots & \mathrm{X}_{n n}
\end{array}\right)=\left(\begin{array}{ccc}
B_{11} & \ldots & B_{1 n} \\
\vdots & \ddots & \vdots \\
B_{n 1} & \cdots & B_{n n}
\end{array}\right)\left(\begin{array}{ccc}
Y_{11} & \ldots & Y_{1 \mathrm{n}} \\
\vdots & \ddots & \vdots \\
Y_{n 1} & \cdots & Y_{n n}
\end{array}\right)
\end{gathered}
$$

$A$ is a $\mathrm{NM} \times \mathrm{NM}$ block input-output coefficient matrix; B denotes the $\mathrm{NM} \times \mathrm{NM}$ block Leontief inverse matrix, and $\mathrm{B}_{c r}$ is the total requirement matrix that gives the amount of gross output in producing country c required for a one-unit increase in final demand in destination country $\mathrm{r} ; \mathrm{X}_{\mathrm{cr}}$ is a $\mathrm{M} \times 1$ gross output vector that gives gross output produced in c and absorbed in $\mathrm{r}$, where $X_{c}=\sum_{r}^{N} X_{\mathrm{cr}}$ is a $\mathrm{M} \times 1$ gross output vector. In addition, Let $V_{c}$ be a $1 \times \mathrm{M}$ matrix with direct value-added coefficients, and $V_{c}=1-\sum a_{r c}$.The gross exports of country $\mathrm{c}$ is denoted by $\mathrm{M} \times \mathrm{M}$ diagonal matrix $\mathrm{E}_{\mathrm{c}}$, and $E_{c}=\sum_{r \neq c}\left(F_{c r}+A_{\mathrm{cr}} X_{r}\right)$. We can decompose gross trade into different sources of value-added components as follows:

$$
\begin{gathered}
\mathrm{VBE}=\left(\begin{array}{ccc}
V_{1} B_{11} E_{1} & \ldots & V_{1} B_{1 n} E_{n} \\
\vdots & \ddots & \vdots \\
V_{n} B_{n 1} E_{1} & \cdots & V_{n} B_{n n} E_{n}
\end{array}\right) \\
F V_{r}=\sum_{c \neq r} V_{c} B_{c r} E_{r} \quad D V_{r}=V_{r} B_{r r} E_{r}
\end{gathered}
$$

Where FV is the sum of off-diagonal elements along a column in equation (6), which is value-added from foreign sources embodied in a particular country's gross exports. DV shows that the diagonal terms measure domestic value added in gross exports. A country's gross exports are decomposed as followed: 


$$
\begin{aligned}
& E_{r}=\underbrace{\mathrm{V}_{r} B_{r r} \sum_{c \neq r} F_{r c}}_{1}+\underbrace{\mathrm{V}_{r} B_{r r} \sum_{c \neq r} A_{r c} X_{c c}}_{2}+\underbrace{\mathrm{V}_{r} B_{r r} \sum_{c \neq r} \sum_{q \neq r, c} A_{r c} X_{c q}}_{3}+\underbrace{V_{r} B_{r r} \sum_{c \neq r} A_{r c} X_{c r}}_{4}+\underbrace{F V}_{5} \\
& =D V_{r}+F V_{r}
\end{aligned}
$$

Where "1" Domestic value-added embodied in exports of final goods and services absorbed by the direct importer c; " 2" Domestic value-added embodied in exports of intermediate inputs used by the direct importer c to produce its domestically needed products; "3" Domestic value-added embodied in intermediate exports used by the direct importer to produce goods for third countries ("indirect value added exports(IV)") ; " 4"Domestic value-added embodied in intermediate exports used by the direct importer c to produce goods shipped back to source ("reflected domestic value added"); " 5" Value-added from foreign countries embodied in gross exports ("foreign value added used in exports(FV)"). The sum of 1,2,3, and 4 equals domestic value added("DV") in a country's gross exports.

\subsection{Position of Countries within Global Value Chains}

Koopman et al. (2010) constructed an index that helps us to gauge whether a country is likely to be in the upstream or downstream of the global value chain (GVC) in any particular sector. The index is the logarithms of the industry's IV share and FV share in gross exports .

$$
\text { GVC_Position }_{i r}=\operatorname{Ln}\left(1+\frac{I V_{i r}}{E_{i r}}\right)-\operatorname{Ln}\left(1+\frac{F V_{i r}}{E_{i r}}\right)
$$

$\mathrm{IV}_{\text {ir }}$ and $F V_{\text {ir }}$ denote the indirect value-added export of the industry $\mathrm{r}$ in the country $\mathrm{i}$, foreign value added embodied in exports, respectively. $E_{\mathrm{ir}}$ is gross exports value of industry $\mathrm{r}$ in the country $\mathrm{i}$. If the country-sector lies upstream in a supply chain, this index tends to be large, and vice versa. If a country lies upstream in the global value-chain, it participates by producing inputs for others, either by providing raw materials (such as Russia), or by providing manufactured intermediates (such as Japan), or both. IV ratio reflects the extent to which other countries exports rely on domestic products, when its IV ratio is higher than its FV ratio, the index will increase.

\subsection{Data Description}

The data is selected from the World Input-Output Tables (WIOTs), which links the input-output tables of 41 major economies through trade statistics, covering 35 sectors, forming time-series world input-output data, which greatly facilitates the study of the domestic value added of electronics and information manufacturing industry. In October 2015, OECD \& WTO joint database on Trade in Value Added (TiVA) version 2 was published, including 62 economies, covering 34 industries. However, the years only covered are 1995, 2000, 2005 and 2008 to 2011, and it can not provide indirect value-added export (IV), which is difficult to calculate position index in GVC according to equation (8). This paper will choose WIOTs to calculate. The WIOTs is classified according to the ISIC REV.3 classification standard. The electronic and optical equipment (c14) under the WIOTs is chosen to represent the electronic information manufacturing industry. This paper chooses the sample in the period 2000-2011. In addition, China, the United States, Japan, Korea, Canada, Australia, Brazil, India, Russia, Indonesia, Mexico and Taiwan are chosen as the objects of study. These economies not only contain the developed countries, but also include developing countries and regions, the GDP of these economies accounted for $58.41 \%{ }^{3}$ of the world's total GDP in 2014, and these countries and regions are also China's major trading partners. In this paper, STATA12 and MATLABR2009b are used for processing data.

\section{Empirical Analysis}

\subsection{Decomposition of gross exports of electronic information manufacturing industry}

From 2000 to 2011, the domestic value-added ratio of China's electronic information manufacturing industry declined earlier and increased later, from $74.1 \%$ to $62.5 \%$, and then gradually increased to $71.1 \%$ (see Table 1). According to domestic value-added change trend, the industry international division of labor status is in line with "V-shaped" route as Wang Lan (2014) described. After 2005, the domestic

${ }^{3}$ Source: Calculated according to countries' GDP in World Bank in 2014. 
value added obviously showed an upward trend. Analysis of the reasons may be related to changes in the development of Chinese enterprises. Taking China's domestic mobile phone brands Huawei and ZTE for example, to break the long-term Chinese manufacturing industry in the international brand OEM pattern, getting rid of the situation that the core components of international manufacture are under control, they can enforce "flexible outsourcing" and "self-made" strategy when investing intermediate goods (Chen Yu, Huang Jinglei, 2014), the domestic value-added included in the domestic mobile phones exported to other countries has been enhanced, and China's domestic mobile phone have gradually embarked on the path of globalization and high-end. However, compared with other countries, China's domestic value-added ratio is always lower than the United States, Japan, India and other countries, indicating the fact that China still lies in downstream of GVC.

Table 1 China's domestic value-added ratio of electronic information manufacturing industry

\begin{tabular}{c|c|c|c|c|c|c|c|c|c|c|c|c}
\hline & 2000 & 2001 & 2002 & 2003 & 2004 & 2005 & 2006 & 2007 & 2008 & 2009 & 2010 & 2011 \\
\hline China & 74.1 & 74.6 & 71.8 & 67.2 & 62.5 & 62.4 & 64.0 & 65.3 & 68.8 & 73.2 & 70.7 & 71.1 \\
US & 85.5 & 86.7 & 87.8 & 88.0 & 84.6 & 84.9 & 84.8 & 84.5 & 84.8 & 88.6 & 88.9 & 88.6 \\
Japan & 90.5 & 89.6 & 90.0 & 90.0 & 89.5 & 88.2 & 86.2 & 85.0 & 83.2 & 86.5 & 85.1 & 84.0 \\
Australia & 81.0 & 81.4 & 83.9 & 84.9 & 82.1 & 81.2 & 80.6 & 79.6 & 78.9 & 80.5 & 81.0 & 79.8 \\
Canada & 61.5 & 60.6 & 61.6 & 63.8 & 64.1 & 65.7 & 66.4 & 67.2 & 65.9 & 67.4 & 67.6 & 67.4 \\
Brazil & 77.6 & 76.4 & 76.8 & 77.7 & 76.3 & 78.6 & 78.5 & 81.7 & 78.2 & 81.4 & 80.4 & 77.9 \\
India & 82.2 & 81.8 & 82.2 & 83.0 & 80.2 & 79.9 & 76.1 & 76.1 & 79.2 & 80.8 & 81.0 & 80.6 \\
Mexico & 45.1 & 46.5 & 46.3 & 44.2 & 41.2 & 41.6 & 41.6 & 42.6 & 42.9 & 43.5 & 40.6 & 39.0 \\
Korea & 64.9 & 65.1 & 66.5 & 65 & 65.2 & 65.4 & 65.9 & 65.0 & 59.3 & 61.8 & 63.1 & 63.2 \\
Russia & 83.3 & 82.2 & 84.1 & 83.3 & 85.9 & 86.0 & 85.7 & 86.6 & 87.1 & 89.0 & 88.4 & 87.2 \\
Taiwan & 55.2 & 57.2 & 57.4 & 55.5 & 51.9 & 51.0 & 50.2 & 50.5 & 51.2 & 54.2 & 50.9 & 51.8 \\
Indonesia & 69.4 & 69.3 & 73.2 & 75.7 & 71.9 & 70.3 & 74.2 & 73.6 & 68.5 & 72.9 & 71.0 & 69.3 \\
\hline
\end{tabular}

Source: Calculated and sorted according to WIOTs.

This paper measures the different sources of value-added in gross exports among major countries over 2001-2011. Due to space limitation, Table 2 only shows decomposition of gross exports in 2001 and 2011. It could be found that in 2001, China's total export value among these countries, ranked third after the United States and Japan, but the share of domestic value added in exports was at the seventh place, not only lower than Japan, the United States and other developed countries, but even lower than India, Brazil and other developing countries. In 2011, China's total export value was the first, the proportion of domestic value added was still at No. 7, indicating that China's electronic information industry seems to have a large export trade for a long time, but which in fact contains a large number of foreign-created value, that is, China's demand for imported intermediate products is relatively large. Chinese enterprises mainly play the role of "migrant workers". Traditional statistics on trade values exaggerates the export value created by China. The United States and Japan and other countries are dominant position in the international division of labor. At the same time, it should be noted that in 2004 China's total export value ranked first, the share of domestic value added in exports accounted for 10, indicating that with the fully participating in GVCs, recently China's electronics and information manufacturing export situation has improved .

According to table 3, first, the share of domestic value added embodied in the final goods decreased from $40.01 \%$ in 2000 to $35.69 \%$ in 2011 , indicating that the trend that its exports are consumed directly as final goods abroad is weakening. Second, through the proportion of China's DV embodied in intermediate exports used by the direct importer to produce goods shipped back to source was small, but obviously maintained upward trend, from $0.94 \%$ in 2000 rose to $2.48 \%$ in 2011 , indicating that the industry begin to accelerate the pace of overseas production. Third, the overall trend of FV gradually increased from $25.92 \%$ in 2000 to $28.91 \%$ in 2011 , indicating that with the deepening of the GVCs division of labor, more and more countries participate in China's exports. The trade gains are distributed across countries. Finally, the proportion of double counted increased from $26.86 \%$ in 2000 to $31.39 \%$ in 2011 , and even reached $39.14 \%$ in 2005 , indicating that based on the traditional statistical methods, the 
total trade value will contain more and more foreign value, it is difficult to reflect the real situation of China in the international trade.

Table 2 Decomposition of gross exports of electronic information manufacturing industry

\begin{tabular}{c|c|c|c|c|c|c}
\hline \multirow{2}{*}{} & \multicolumn{3}{|c|}{2001} & \multicolumn{3}{c}{2011} \\
\cline { 2 - 7 } & $\begin{array}{c}\text { Gross ex- } \\
\text { ports(millions } \\
\text { of US\$) }\end{array}$ & $\begin{array}{c}\text { Domestic } \\
\text { value added } \\
\text { ratio }\end{array}$ & $\begin{array}{c}\text { Foreign value } \\
\text { added ratio }\end{array}$ & $\begin{array}{c}\text { Gross ex- } \\
\text { ports(millions } \\
\text { of US\$) }\end{array}$ & $\begin{array}{c}\text { Domestic } \\
\text { value added } \\
\text { ratio }\end{array}$ & $\begin{array}{c}\text { Foreign value } \\
\text { added ratio }\end{array}$ \\
\hline China & 74270.56 & $74.61 \%$ & $25.39 \%$ & 721416.59 & $71.09 \%$ & $28.91 \%$ \\
US & 163594.67 & $86.67 \%$ & $13.33 \%$ & 223011.74 & $88.60 \%$ & $11.40 \%$ \\
Japan & 107056.75 & $89.58 \%$ & $10.42 \%$ & 166934.56 & $83.96 \%$ & $16.04 \%$ \\
Australia & 1670.62 & $81.35 \%$ & $18.65 \%$ & 3481.42 & $79.79 \%$ & $20.21 \%$ \\
Canada & 21499.20 & $60.55 \%$ & $39.45 \%$ & 24582.42 & $67.42 \%$ & $32.58 \%$ \\
Brazil & 3956.41 & $76.38 \%$ & $23.62 \%$ & 9916.40 & $77.95 \%$ & $22.05 \%$ \\
India & 2363.26 & $81.80 \%$ & $18.20 \%$ & 29470.50 & $80.57 \%$ & $19.43 \%$ \\
Mexico & 46133.72 & $46.47 \%$ & $53.53 \%$ & 71396.62 & $39.04 \%$ & $60.96 \%$ \\
Korea & 47965.65 & $65.14 \%$ & $34.86 \%$ & 159191.32 & $63.16 \%$ & $36.84 \%$ \\
Russia & 1319.03 & $82.16 \%$ & $17.84 \%$ & 2796.91 & $87.23 \%$ & $12.77 \%$ \\
Taiwan & 64455.51 & $57.24 \%$ & $42.76 \%$ & 147645.94 & $51.80 \%$ & $48.20 \%$ \\
Indonesia & 7596.17 & $69.34 \%$ & $30.66 \%$ & 12557.91 & $69.29 \%$ & $30.71 \%$ \\
\hline
\end{tabular}

Source: Calculated and sorted according to WIOTs.

Table 3 Decomposition of gross exports of electronic information manufacturing industry

\begin{tabular}{c|c|c|c|c|c|c|c}
\hline & \multirow{2}{*}{$\begin{array}{c}\text { Domestic value } \\
\text { added (\%) }\end{array}$} & $\begin{array}{c}\text { DV in direct ex- } \\
\text { ports of final } \\
\text { goods(\%) }\end{array}$ & $\begin{array}{c}\text { DV in exports as } \\
\text { intermediates(\%) }\end{array}$ & $\begin{array}{c}\text { Returned } \\
\text { DV(\%) }\end{array}$ & $\begin{array}{c}\text { Foreign } \\
\text { value } \\
\text { added(\%) }\end{array}$ & $\begin{array}{c}\text { Total } \\
(\%)\end{array}$ & $\begin{array}{c}\text { Double } \\
\text { counted } \\
(\%)\end{array}$ \\
\hline 2000 & 74.08 & 40.01 & 33.13 & 0.94 & 25.92 & 100 & 26.86 \\
2001 & 74.61 & 40.79 & 32.63 & 1.19 & 25.39 & 100 & 26.58 \\
2002 & 71.84 & 40.37 & 30.04 & 1.44 & 28.16 & 100 & 29.59 \\
2003 & 67.22 & 38.4 & 27.26 & 1.57 & 32.78 & 100 & 34.34 \\
2004 & 62.55 & 31.83 & 29.15 & 1.57 & 37.45 & 100 & 39.02 \\
2005 & 62.44 & 32.64 & 28.22 & 1.57 & 37.56 & 100 & 39.14 \\
2006 & 64.05 & 32.69 & 29.59 & 1.77 & 35.95 & 100 & 37.72 \\
2007 & 65.29 & 33.66 & 29.89 & 1.73 & 34.71 & 100 & 36.45 \\
2008 & 68.84 & 36.03 & 30.95 & 1.86 & 31.16 & 100 & 33.02 \\
2009 & 73.19 & 38.52 & 32.36 & 2.3 & 26.81 & 100 & 29.11 \\
2010 & 70.68 & 35.6 & 32.64 & 2.45 & 29.32 & 100 & 31.77 \\
2011 & 71.09 & 35.69 & 32.93 & 2.48 & 28.91 & 100 & 31.39 \\
\hline
\end{tabular}

Source: Calculated and sorted according to WIOTs.

\subsection{Electronic information manufacturing industry's GVC position index and participation}

Figure 1 shows the chang trends of the industry GVC position index and participation from 2000 to 2011. After 2004, there was a negative correlation between the two, the position index had a weak upward trend, while the degree of participation in GVCs had been declining. The analysis of the causes of this evolution may be related to China's comparative advantage and the adjustment of development strategy in the process of industrialization. In the early 90's, China was labor-rich and capital scarcity, labor costs were relatively cheaper. But electronic information manufacturing industry belongs to "technology and capital-intensive" manufacturing industry, it needs to be put in a lot of technical equipment and funds. However, at that stage, China's manufacturing industry could not grasp the R\&D, could only participate in the assembling and processing links with low technology content and low value added in GVCs. But this did not meet the interests of China, was likely to face comparative advantage in the lock.

As shown in Table 4, the gap of the index of international division of labor between China and other countries is very obvious, and China lies downstream in GVC. From 2000 to 2011, China's GVC position index was negative, i.e., its value added in imports of intermediate goods was greater than that of exports of intermediate goods, relying on the intermediate goods supplied by the upper reaches of in- 
ternational manufacturers too much, which largely reflects that China doesn't have the innovation ability in key spare parts and hasn't formed a competitive advantage in the R\&D design of the value chain. While Japan masters the core competitiveness of the industry, and always lies upstream in GVC.

With the accelerated process of industrialization and a large number of foreign direct investment (FDI) into China, the "spillover effect" and "learning effect" speed up accumulation of capital, technology and knowledge. At the same time, the government encourages enterprises to strengthen independent innovation ability and pay attention to information, network and other infrastructure investment. China's manufacturing industry begins to move in a new direction of improving competitiveness, try to establish their own core technology and brand, that is to get rid of dependence on imports of intermediate goods, exporting intermediate goods into the international division of labor system to enhance the international value chain status.

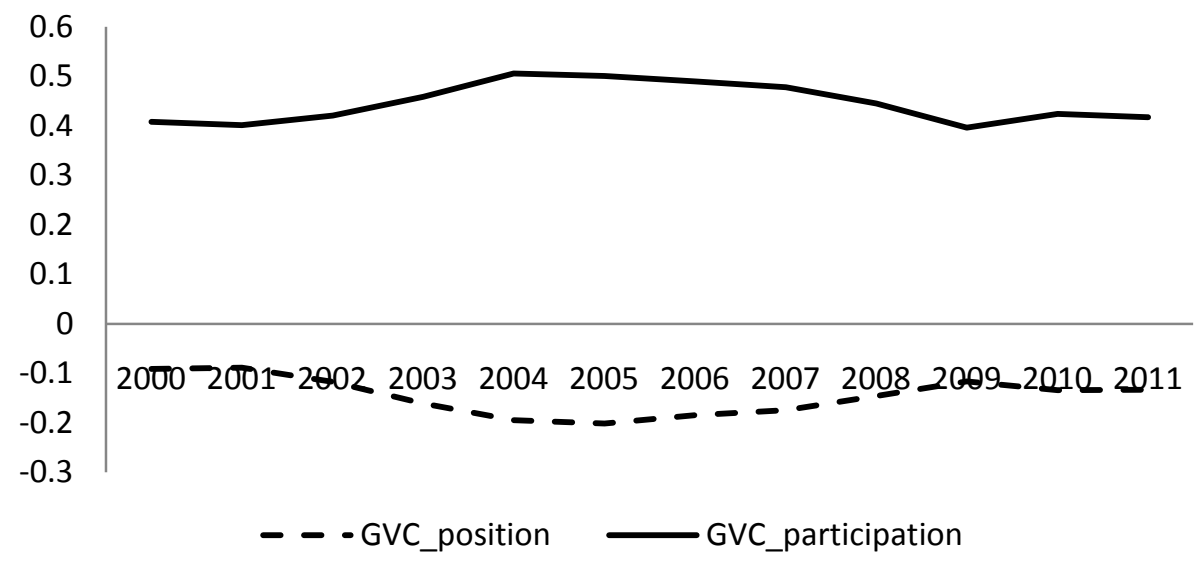

Figure 1 China's electronic information manufacturing industry's GVC position index and participation

Table 4 Electronic information manufacturing industry's GVC position index

\begin{tabular}{l|c|c|c|c|c|c|c|c|c|c|c|r}
\hline & China & US & Japan & Australia & Canada & \multicolumn{1}{c}{ Brazil } & India & Mexico & Korea & Russia & Taiwan & Indonesia \\
\hline 2000 & -0.092 & 0.007 & 0.104 & -0.016 & -0.262 & -0.033 & 0.022 & -0.398 & -0.140 & 0.025 & -0.237 & -0.123 \\
2005 & -0.201 & 0.033 & 0.122 & -0.005 & -0.220 & 0.012 & 0.005 & -0.402 & -0.086 & 0.071 & -0.202 & -0.079 \\
2009 & -0.117 & 0.061 & 0.086 & -0.061 & -0.197 & 0.002 & -0.047 & -0.396 & -0.148 & 0.083 & -0.180 & -0.087 \\
2010 & -0.134 & 0.072 & 0.076 & -0.042 & -0.183 & 0.011 & -0.020 & -0.414 & -0.119 & 0.099 & -0.206 & -0.097 \\
2011 & -0.133 & 0.057 & 0.054 & -0.057 & -0.186 & -0.018 & -0.021 & -0.426 & -0.133 & 0.062 & -0.209 & -0.128 \\
\hline
\end{tabular}

Source: Calculated and sorted according to WIOTs.

\section{Conclusions and Inspiration}

Under globalization background, more and more countries participate in the global production chain, the system of traditional statistics on trade values does not truly reflect the trade interests of each country. This paper aims to measure countries' real position on international division of labor from the aspect of value added. The study finds: First, the share of domestic value-added in gross exports follows a "V-shaped" route. After 2005 the domestic value-added showed a obviously upward trend, but domestic value-added ratio was always lower than the United States, Japan, India and other countries; Second, China's export trade of electronic information industry seems large for a long time, but in fact contains a large number of foreign value-added, that is, China's demand for importing intermediate products is relatively large; Third, the trend that China's exports are consumed directly as final goods abroad is weakening. Its trade value was seriously overestimated, and double counted increased from $26.86 \%$ in 2000 to $31.39 \%$ in 2011; Fourth, the gap of the index of international division of labor in electronic information manufacturing industry between China and other countries is very obvious, and China is in the downstream of the value chain. Therefore, China should strengthen the R\&D and design capability of key components, and form a competitive advantage in the upstream $\mathrm{R} \& \mathrm{D}$ sector of value chain. 


\section{References:}

[1] Hummels D, Ishii J, Yi K M. The Nature and Growth of Vertical Specialization in World Trade[J].Journal of International Economics, 2001,(54):75-96

[2] Koopman R, Powers W, Wang Z, et all. Give Credit to Where Credit is Due: Tracing Value Added in Global Production[R] .NBER Working Paper No.6426,2010

[3] Daudin G, Rifflart C, Schweisguth D. Who Produces for Whom in the World Economy?[J].Canadian Journal of Economics , 2011, 44(4): 1409-1538

[4] Johnson ,Robert, Noguera G. Accounting for Intermediates: Production Sharing and Trade in Value-added[R]. NBER ITI Program Meeting,2010

[5] Johnson R C, Noguera G. Accounting for Intermediates: Production Sharing and Trade in Value-added[J]. Journal of International Economics,2012, 86 (2):224-236

[6] Chen yu, Huang jinglei, Tan Rongjuan. Adverse Outsourcing, Rents of Global Value Chain, and Industrial Upgrading of Developing Country[J] .Industrial Economics Research,2014,(04):1-12

[7] Song Yuhua, Zhang Haiyan. Deconstruction of Asia-Pacific Value Chain and Analysis on China's Gains: Based on the Input-output Analysis among APEC Main Countries[J].Pacific Economic Review, 2014,(02):52-59

[8] Wang Lan. The Impact of Integrating Global Value Chains into China Manufactures' Position on International Division of Labor[J].Statistical Research,2014,(05):17-23

[9] Li Jinchang, Xiang Ying. Analysis on the Value-added Share and Country(Region) Sources of Export in China's Manufacturing Industry-Based on the World Input-Output Tables within the Framework[J]China Industrial Economic,2014,(08):84-96

[10]Zhou Shengqi, Lan Zhenxian, Fu Hua. Division Status of China's Manufacturing Industry in Global Value Chains: A Study Based on Koopman's GVC Position Indices[J].Journal of International Trade,2014,(2):3-12 